\title{
Transmission, Chassis and Materials
}

(381 part 2 including Applied Studies)

\section{Editor Roy Brooks}

$$
\begin{aligned}
& \text { Name..... } \\
& \text { College ... } \\
& \text { Employer }
\end{aligned}
$$

\begin{tabular}{|c|c|c|c|c|c|c|c|}
\hline Session & & Class & Ref. No. & Session & & Class & Ref. No. \\
\hline Day and Time & Room & Subject & Teacher & Day and Time & Room & Subject & Teacher \\
\hline & $\cdots$ & $\ldots$ & $\ldots$ & $\ldots$ & & $\cdots$ & $\ldots$ \\
\hline$\cdots$ & $\ldots \ldots$ & $\cdots$ & $\ldots \ldots \ldots$ & . & $\ldots \ldots$ & $\cdots$ & . \\
\hline$\ldots \ldots \ldots \ldots \ldots$ & $\ldots \ldots$ & $\cdots$ & $\ldots \ldots \ldots \ldots$ & $\ldots \ldots \ldots$ & $\ldots \ldots$ & $\cdots$ & ... \\
\hline$\ldots \ldots \ldots \ldots \ldots$ & $\ldots$ & $\cdots$ & . & $\cdots$ & $\ldots \ldots$ & $\ldots$ & $\ldots$ \\
\hline$\ldots \ldots \ldots \ldots \ldots$ & $\ldots \ldots$ & $\ldots \ldots \ldots$ & $\ldots \ldots \ldots$ & $\ldots \ldots \ldots \ldots \ldots$ & $\ldots \ldots$ & $\ldots \ldots \ldots \ldots \ldots$ & $\ldots \ldots \ldots \ldots$ \\
\hline$\ldots \ldots \ldots \ldots \ldots$ & $\ldots \ldots$ & $\ldots \ldots \ldots \ldots$ & $\ldots \ldots \ldots$ & $\ldots \ldots \ldots \ldots \ldots$ & $\cdots$ & $\ldots \ldots \ldots$ & \\
\hline
\end{tabular}




\title{
Macmillan Motor Vehicle Craft Studies Series
}

\section{Part 2 Motor Vehicle Craft Studies \\ Transmission, Chassis and Materials} (381 part 2 including Applied Studies)

\author{
Editor Roy Brooks \\ Senior Lecturer in Motor Vehicle Subjects \\ Bolton Institute of Higher Education \\ Author John Whipp \\ Senior Lecturer in Motor Vehicle Subjects \\ Moston College of Further Education
}


Ail rights reserved. No part of this publication may be reproduced or transmitted,

in any form or by any means, without permission.

First published 1982 by

THE MACMILLAN PRESS LTD

London and Basingstoke

Companies and representatives throughout the world

ISBN 978-1-349-06645-2 ISBN 978-1-349-06643-8 (eBook)

DOI 10.1007/978-1-349-06643-8

The paperback edition of this book is sold subject to the condition that it shall not, by way of trade or otherwise, be lent, resold, hired out, or otherwise circulated without the publisher's prior consent in any form of binding or cover other than that in which it is published and without a similar condition including this condition being imposed on the subsequent purchaser. 


\section{Contents}

Clutches

Hydraulic couplings and torque converters

Gearboxes

Universal joints, propeller shafts and drive

arrangements

Final drive, differential, and axle shafts

Tyres and wheels

Suspension

Steering

Braking systems

The contents follow, as far as practicable, the order of the City and Guilds syllabus. This often may well not be the best teaching/learning sequence, but it ensures a uniformly understandable order of presentation.

The publisher will be happy to suggest an effective scheme of work based on page numbers. 


\section{PREFACE}

This book deals with vehicle transmission, suspension, steering, braking, body/chassis structure, materials and material joining as required by the syllabus 381 part 2 Light and Heavy Vehicle Mechanics, 'Transmission, Chassis and Materials'. The author, John Whipp, is head of the Motor Vehicle Section of the Moston College of Further Education, Manchester. He has had wide practical and teaching experience in these fields, as well as being a leading author in the earlier highly successful books in the Macmillan Motor Vehicle Craft Studies Series.

As before, the requirements of the City and Guilds syllabus have been faithfully adhered to. Similarly the book's aim is to save both student and teacher time in coping with the heavy demands of a necessarily very full syllabus.

Naturally the maximum benefit from this workbook will be realised if it is used in conjunction with its companion volume. This is Engines and Electrics by Jack Hirst, also a fully experienced series author. Anyone conscientiously completing these two books should easily pass their examinations in the appropriate topic areas.

Clearly the book is suitable for both Light and Heavy vehicle mechanics since very substantial areas of their work overlap. Where divergences do occur, then by taking note of the precise syllabus references (shown on each page), such sections can be omitted if desired.

Whilst wishing every success to those who use the books in this series, the production team realise that improvements are always possible.

Constructive comments will be welcome. Send them to me, please, via the publishers - they will be most carefully considered. 


\section{ACKNOWLEDGEMENTS}

The editor and author wish to thank the very many organisations and individuals who have assisted with information and illustrations for this book. In some instances the results may not be easily recognisable: for example, where simplified to suit teaching requirements. None the less, their help is greatly appreciated, in particular the following:

George Angus \& Co. Ltd

Automotive Products Ltd Bendix Westinghouse Ltd

BL Cars Ltd

Citroèn Cars Ltd

Clayton Dewandre Co. Ltd

Dunlop Ltd

Fiat Auto (UK) Ltd

Girling Ltd

Lucas Industries Ltd

Metalastic Ltd

Telma Retarder Ltd

VAG (United Kingdom) Ltd

Vauxhall Motors Ltd

The motor vehicle staff of Moston College of Further Education 